\title{
THE INFLUENCE OF COUNTRY OF ORIGIN AND BRAND IMAGE ON PURCHASE INTENTION OF OPPO SMARTPHONE WITH PERCEIVED QUALITY AS INTERVENING VARIABLES
}

\author{
Setyo Aji Wibowo ${ }^{1}$ \\ ${ }^{1}$ Faculty of Economics, Universitas Negeri Jakarta \\ Jakarta, Indonesia \\ ajistark91@gmail.com \\ Mohamad Rizan ${ }^{2}$ \\ ${ }^{2}$ Faculty of Economics, Universitas Negeri Jakarta \\ Jakarta, Indonesia \\ mohamadrizan72@unj.ac.id \\ Ika Febrilia ${ }^{3}$ \\ ${ }^{3}$ Faculty of Economics, Universitas Negeri Jakarta \\ Jakarta, Indonesia \\ ikafebrilia@unj.ac.id
}

\begin{abstract}
This study provides empirical testing to test the influences of the country of origin and brand image on purchase intention of Oppo Smartphone and perceived quality as the mediating variable. The research object uses a survey method with instruments in the form of questionnaires. The number of respondents to this study was 216 respondents from State University of Jakarta who had or are currently using Oppo Smartphone. The data analysis in this study used SPSS version 22 and Structural Equation Model (SEM) with LISREL version 8.80 program. The results of this study show that country of origin has a positive and significant influence on perceived quality, brand image has a positive and significant influence on perceived quality, country of origin has a positive but not significant influence on purchase intention, brand image has a positive but not significant influence on purchase intention, perceived quality has a positive and significant influence on purchase intention, perceived quality can mediate influence country of origin on purchase intention, perceived quality can mediate influence brand image on purchase intention. Implications for managerial: Oppo must maintain or
\end{abstract}


improve its ability to produce high-quality smartphone products, Oppo must improve its brand image, namely as a smartphone brand that always releases smartphones with sophisticated and latest features, Oppo must continue to improve product quality, both in terms of performance and physical resistance smartphone product. Consumer interest can arise because of perceptions about the quality of the product or the brand image of the product, Oppo must be able to attract consumers attention.

Keywords: Country of Origin, Brand Image, Perceived Quality, Purchase Intention, Oppo Smartphone

\section{INTRODUCTION}

In this era of globalization, geographical boundaries are no longer an obstacle in communication and interaction between individuals. This is due to developments in communication technology, especially in mobile phone technology, where at this time, mobile phones have evolved into smartphones. Smartphone users continue to experience an increase. eMarketer data states that in the last five years, smartphone users in Indonesia grew from 38.3 million in 2014 to 52.2 million, 69.4 million, 86.6 million, and 103 million in 2018 (Purwanto, 2019). The high demand for smartphones in the market makes smartphone manufacturers from various countries aggressively launch their smartphone products regularly, which always presents the latest innovations to meet consumer needs to attract their buying interest.

In growing their buying interest, some consumers are influenced by the country of origin of the product. Alternatively usually, it can be seen from the "made in" label on a product (Parlina, 2017). The label can be a stimulus that gives rise to consumer perceptions of a product from a particular country. This perception can later influence consumers in making purchases. One aspect that is often used as a reference related to the country of origin is the brand image. Brand image is a set of beliefs, ideas, impressions that a person has of a brand. A good brand image is an important thing that must be owned by a company because it can be the basis for influencing consumer purchase intentions. Brand 
image has a positive influence on consumer purchase intention (Fauziyyah et al., 2018). Brand image can generate consumer interest in certain products or services. The more consumers recognize a brand, the greater their buying interest (Mohamed et al., 2019). Buying interest arises when someone has obtained sufficient information about the desired product. Purchase intention is a purchase interest that shows the customer's desire to make a repeat purchase (Assael, 2002). Research conducted by Dinata et al. (2015) shows that the country of origin positively influences the buying interest of potential consumers who want to buy an iPad in Indonesia. Another study conducted by Gibran (2018) states that the country of origin has a positive effect on purchase intention. The country of origin of a country impacts the purchase intention of consumers towards products from that country. Furthermore, Rafida \& Saino (2015) research shows that there is a significant influence between perceived quality on interest in buying Oppo smartphones.

One of the countries with the most smartphone manufacturers is China. However, at first, smartphones from China were hit by a negative stigma that Chinese products only excelled at low prices but had low quality. The consumer's view that "price determines quality" makes smartphone products from China not much in demand. Another negative stigma attached to products from China is "plagiarism". Chinese products are synonymous with counterfeit goods. Newly launched products can be easily imitated with the label "made in china". These negative stigmas are supported by the presence of several fewer positive reviews from consumers regarding the quality of smartphone products from China. Like, the build quality of the product is not good on the Oppo Smartphone product. Oppo often presents mobile phone products with product quality that is sometimes not as good as competitors. Although the physical design of smartphones is now excellent and attractive, the primary material for making it still uses a plastic material, so the smartphone feels less sturdy. The sturdiness of the Oppo smartphone was tested by Jerry Rig Everything, an overseas YouTube channel that often tests the durability of a smartphone. The channel once tested the durability of the Oppo Find X, and the result was that the smartphone was so easy to bend with both hands. Even though the Oppo Find $\mathrm{X}$ is an Oppo product which is quite expensive (Nugraha, 2019). Although there are fewer positive reviews of several smartphone products from China, it does not demand its 
decrease. Even the smartphone market share in Indonesia is controlled and dominated by smartphone brands from China.

Oppo is a Chinese brand that entered the Indonesian market. To change the negative stigma on cellphone products from China, Oppo seeks to show the quality of its products by issuing premium smartphone products. Oppo began to attract the response of smartphone users in Indonesia in 2013. Since then, Oppo has continued to strive for aggressive marketing, improving features and designs. Oppo managed to enter the top five smartphone market share in Indonesia. Table 1 shows that Oppo smartphones originating from China are superior to other Chinese products. It can be interpreted that in 2018-2019 Oppo smartphones have an apparent increase, and more and more consumers are interested in buying Oppo smartphones. Considering that Oppo smartphones come from China, where the country perceives being a "plagiarist of everything" country by implementing a system of producing more and cheaper.

Furthermore, getting some bad reviews. However, based on Table 1, Oppo is in second position smartphone with the highest market share in Indonesia. This raises whether Oppo smartphones have dismissed consumer perceptions of their country of origin with the quality offered by Chinese products in influencing consumer buying interest. So, researchers are interested in conducting this research.

Table 1. Smartphone Market Share in Indonesia

\begin{tabular}{llccc}
\hline No. & Brand Name & \multicolumn{3}{c}{ Market Share } \\
\cline { 3 - 5 } & & $2018 \mathrm{Q} 4$ & $2019 \mathrm{Q} 1$ & $2019 \mathrm{Q} 2$ \\
\hline 1 & Samsung & $27,0 \%$ & $31,8 \%$ & $26,9 \%$ \\
2 & Oppo & $19,7 \%$ & $23,2 \%$ & $21,5 \%$ \\
3 & Vivo & $11,8 \%$ & $14,9 \%$ & $17,0 \%$ \\
4 & Xiaomi & $20,7 \%$ & $10,8 \%$ & $16,8 \%$ \\
5 & Realme & $1,6 \%$ & $1,4 \%$ & $6,1 \%$ \\
6 & Others & $19,2 \%$ & $17,8 \%$ & $11,7 \%$ \\
\hline & Total & $100,0 \%$ & $100,0 \%$ & $100,0 \%$ \\
\hline
\end{tabular}

Source: IDC Quarterly MobilePhone Tracker 2019 Q2 


\section{LITERATURE REVIEW}

\section{Country of Origin}

According to Diamantopoulos \& Zeugner-Roth (2011) in Wu et al. (2016), the country of origin effect is the impact of the name of the country on how consumers view and evaluate products made in the country. According to Knight \& Calantone (2000) in Lee et al. (2014), a country of origin image is an indication that comes from outside regarding the reflecting product consumer perceptions of a particular country and the quality of the products they make. According to Jaffe \& Nebenzahl (2006) in Hien et al. (2020), a country of origin image is defined as the image of a country where consumers associate a particular product or brand with the country of origin. According to Cateora \& Graham (1999) in Yunus dan Rashid (2016), country of origin can be defined as any influence that a producing country has on consumers' positive or negative perceptions of a product. To measure the country of origin, Laroche et al. (2005), having a concept that consists of three indicators, namely: 1) Country Belief: This is what potential consumers believe about industrial development and technological advances in the country origin of the product brand, 2) People Affect: Is a response-affective-potential-consumers to the people of the country of origin product brand, 3) Desire Interaction: Is the willingness or desire of potential consumers to build relationships with the country.

\section{Brand Image}

Brand image is a target and mental feedback consumers when they buy products (Mehta $\&$ Tariq, 2020). The brand image creates value for the company making it easier for consumers to find information about the product and help create that association generates pervasive positive feelings and attitudes to other products under the same brand (Ali et al., 2017). Brand image is the character and beliefs that consumers have in their minds about a brand in the form of products or services offered (Thaichon \& Quach, 2015). Brand image is the interpretation of the target market on product attributes, benefits, uses, and product characteristics. In other words, the brand image includes everything that consumers think and feel when they hear or see the brand (Hawkins \& Mothersbaugh, 2014). Brand image is part of the brand that can be recognized but cannot be spoken, such as a symbol, unique lettering or colour design, or the customer's perception of a product or service that the brand represents (Budiastari, 2018). 
According to Aaker \& Biel (2009), some indicators that can form a brand image are as follows: 1) Corporate Image: Is a collection association that consumers perceive the company which makes a good or service. Includes popularity, credibility, corporate network, and the users themselves, 2) Product Image: Is a set-associations that consumers perceive to an item or service. Includes attributes of the product, benefits for consumers, guarantees, 3) User Image: This is a set of associations that consumers perceive against users who use a good or service. Includes the user himself, as well as his social status.

\section{Perceived Quality}

Perceived quality is defined by a brand that offers good conventional performance which is considered a product attribute so that it can be accepted by consumers (Alietal., 2017). Perceived quality is the consumer's assessment of accumulated product usage and subjective feelings towards product quality (Listiana, 2015). Consumer perceptions are defined thoughts or beliefs held by consumers regarding the marketing stimuli of a company when they try to deduce ulterior motives company (Ahn, 2015). Erdogmus \& Turan (2012) in Abdelkader (2015), stated that the perception of quality is a consumer's assessment of the superiority of a product based on subjective perceptions.

Several dimensions underlie the assessment perceived quality of goods (Garvin, 1987). among others: 1) Performance: Related to functional aspects of a product and is the main characteristic that consumers consider when are currently buying the product, 2) Feature: Related to the performance aspects useful for adding basic, related functions with product options as well as product development, 3) Reliability: Related to the probability or likelihood of a product being successful performs its function every time or is used in period-of-time and certain conditions, 4) Conformance Quality: Related to the level of conformity in terms of the predetermined specifications based on consumer desires, 5) Durability: A reflection on economic life in the form of a measure of durability or service life of a product (goods), 6) Serviceability: Characteristics related to competence, speed, accuracy, and ease of delivery service for repair of a product (goods), 7) Esthetic: A characteristic that is subjective about aesthetic values related to consideration personal as well as a reflection of an individual's preferences. 


\section{Purchase Intention}

According to Belch (2004) in Arafah et al. (2019), purchase intention is a match between motives purchases with the attributes or characteristics of brand products that have been previously considered for the next product purchase process. According to Spears $\&$ Singh (2004) in Talwar et al. (2020), purchase intention is defined as a plan made consciously by consumers to try to buy a product or specific brand. According to Fishbein \& Ajzen (1975) in Khan et al. (2015), Purchase intention is a consumer's personal preference for a product and is an essential factor in predicting consumer behaviour. According to Schiffman \& Kanuk (2007) in Foster \& Johansyah (2019), buying interest is a psychological force within a person that influences their buying actions.

According to Ferdinand (2002), buying interest can be identified through four indicators, namely: 1) Transactional Interest: Namely a person's tendency to buying a product, 2) Referential Interest: That is a tendency for someone to reference a product that others have purchased, 3) Preferential Interest: Which describes the behaviour of someone who has the primary preference for products that have been consumed. This preference can only be changed if something happens with the product of his preference, 4) Explorative Interest: Ie describes someone who is always looking for information about the product that he is interested in and looking for information to support the favourable properties of the product.

\section{Conceptual Framework}

$\mathrm{H}_{1}$ : Country of origin affects perceived quality

Research conducted by Abdelkader (2015), shows the country of origin has a significant effect significant to perceived quality. Same result too found in research conducted by Le et al. (2017), which shows that the country-of-origin is influential significant to perceived product quality. However, in research conducted by Listiana (2015), country-of-origin does not have a significant effect against perceived quality.

$\mathrm{H}_{2}$ : Brand image affects perceived quality

In research conducted by Wang \& Tsai (2014), shows that a positive brand image has an influence that is significant on perceived quality. Invention this is following the research conducted by Khan et al. (2015), which shows that the brand image affects perceived 
quality. However, research done by Hanna(2019), showing that the brand image does not have a significant effect on perceived quality.

$\mathrm{H}_{3}$ : Country of origin affects purchase intention

Research conducted by Hien et al. (2020), shows that the country of origin has a significant effect on purchase intention. However, that research conducted by Le et al. (2017), showing that country-of-origin has no significant effect on purchase intention. The findings are also similar to those of the same study conducted by Setiadi et al. (2018), that the relationship between country-of-origin and purchase intention does no effect.

$\mathrm{H}_{4}$ : Brand image affects purchase intention

Research conducted by Mohamed et al. (2019), shows that the brand image is influential significant to purchase intention. Other research which is conducted by Zhang \& Cude (2018), also shows the brand image has a positive and significant effect on purchase intention for luxury clothing. However, research by di Ali et al. (2017), showing that the brand image does not have a significant effect on purchase intention. The same thing was also found in the same study conducted by Foster \& Johansyah (2019), which also shows that the brand image has no positive and significant to purchase intention.

$\mathrm{H}_{5}$ : Perceived quality affects purchase intention

Research conducted by Martati et al. (2020), shows that perceived quality has a direct effect and significant to purchase intention. Research from Choudhuri (2018), also shows that there is an influence significant between perceived quality and online purchasing intention. However, the research conducted by Wong (2021), indicating that perceived quality is not has a significant effect on purchase intention.

$\mathrm{H}_{6}$ : Perceived quality mediates relationship between country of origin and purchase intention

Research conducted by Rafida \& Saino (2015), indicates that there is a significant effect between the country of origin to buying interest with mediation perceived quality. Meanwhile, the research conducted by Kyoet al. (2019), indicating that there is no effect of perceived quality mediators on the relationship between the origin country's image and purchasing intention.

$\mathrm{H}_{7}$ : Perceived quality mediates relationship between brand image and purchase intention 
Research conducted by Ali et al. (2017), shows that the perceived quality brand is capable mediate the relationship between the brand image and the brand purchase intention. The same was found in research conducted by Ali et al. (2020), which shows that the product perceived quality is capable be a mediator variable on the relationship between brands image and consumer intention to purchase.

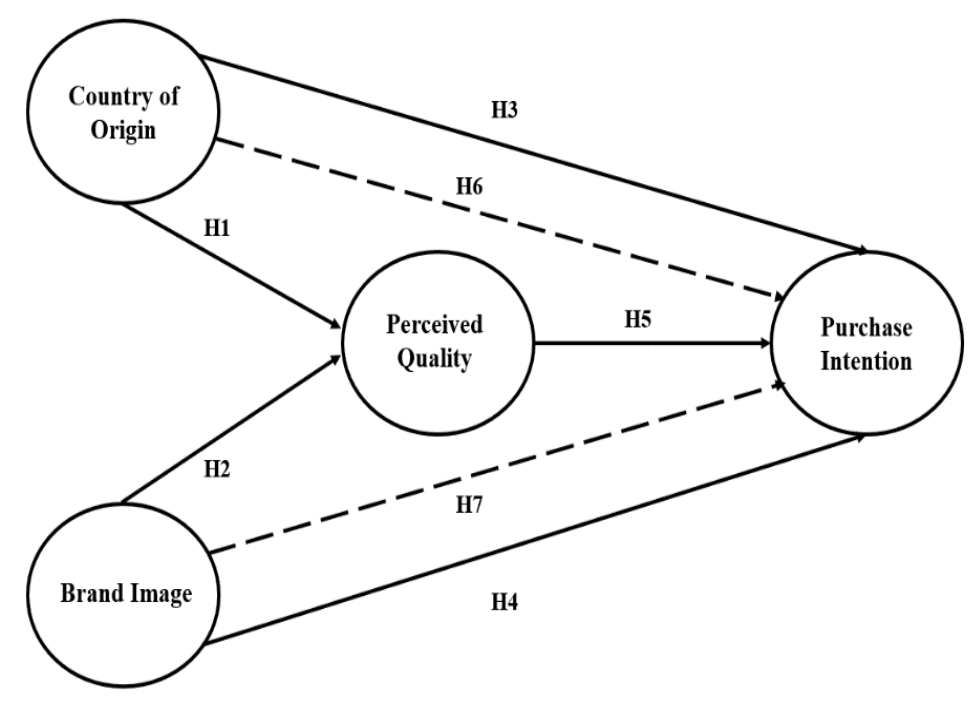

Figure 1. Research Model

Source: Processed by researchers

\section{RESEARCH METHOD}

Population is the whole object to be studied. Members of the population can be living things and inanimate objects and humans, where the characteristics that exist in them can be measured or observed (Syahrum \& Salim, 2012). The population of this study were students from the State University of Jakarta that has been or is using an Oppo smartphone. This type of population is infinite because the number of students at the State University of Jakarta using an Oppo smartphone is unknown in number.

The sampling technique in this study used a non-probability sampling technique. The non-probability sampling technique is a sampling technique in which not all members/elements of the population have the same opportunity to be sampled (Juliandi et al., 2014). Determination of sampling in this study using a purposive sampling approach. Purposive sampling is choosing a sample from a population based on specific 
considerations. The sample is part of the population that is the research object (Syahrum \& Salim, 2012). This technique provides quite strict requirements so that the sample matches the desired characteristics (Juliandi et al., 2014). This technique was chosen because the samples taken must meet the criteria of this study.

The criteria needed by researchers are 1) Jakarta State University students, 2) Have or are currently using an Oppo smartphone. This study uses the Structural Equation Model (SEM) analysis which consists of a certain number of samples. The study uses the maximum likelihood estimation technique in the SEM analysis, namely the research sample with a sample size ranging from 100 to 200 samples. The recommended number of samples is five times the number of indicators (Hair Jr et al., 2010). This study has 31 statements, so the minimum sample size in this study is $31 \times 5=155$. So, the number of samples taken in this study was 155 respondents. However, the selected sample size is as many as 200 people with the consideration to reduce errors. The data analysis technique used in this study used SPSS version 22 software and the Structural Equation Model (SEM) in the LISREL software version 8.80.

The measurement scale used in this study is the Likert scale. The Likert scale is used to measure a person's attitudes, opinions, and perceptions about social phenomena (Sugiyono, 2015). The measurement scale in this study uses an even Likert scale that is used, which amounts to 6 (six) scores consisting of "Strongly Disagree" to a score of "Strongly Agree". (Sukardi, 2015). This aims to eliminate ambiguous values or intermediate values (zero points) (Edwards, 1957).

Data collection techniques in this study used primary data. Primary data is data obtained or collected by researchers directly from the primary data source (Sarwono, 2006). This primary data was taken by survey method. That is, by distributing questionnaires that have been prepared to respondents to obtain measurable and specific information.

\section{RESULT AND DISCUSSION}

\section{Validity Test}

A validity test is a test tool that aims to test the extent of the accuracy or truth of an instrument as a measuring instrument for research variables. If the instrument is valid or correct, the measurement results are likely to be correct (Juliandi et al., 2014). The 
validity test in this study uses the Pearson test, where the indicator is considered valid if the calculated $r$-value is greater than the $r$-table. The $r$ table in this study is 0.1329 , with a significance of $5 \%$ and a sample size of 216 . Then each indicator is said to be valid if the calculated $r-v a l u e$ is greater than 0.1329 .

Table 2. Validity Test Results

\begin{tabular}{|c|c|c|c|c|}
\hline Variables & Item & r-value & r-table $5 \%(\mathrm{~N}=216)$ & Decision \\
\hline & NA1 & 0.881 & 0.1329 & Valid \\
\hline Country & NA2 & 0.910 & 0.1329 & Valid \\
\hline of & NA3 & 0.869 & 0.1329 & Valid \\
\hline Origin & NA4 & 0.900 & 0.1329 & Valid \\
\hline \multirow[t]{5}{*}{$\left(\mathbf{X}_{1}\right)$} & NA5 & 0.891 & 0.1329 & Valid \\
\hline & NA6 & 0.871 & 0.1329 & Valid \\
\hline & NA7 & 0.857 & 0.1329 & Valid \\
\hline & CM1 & 0.861 & 0.1329 & Valid \\
\hline & CM2 & 0.823 & 0.1329 & Valid \\
\hline Brand & CM3 & 0.851 & 0.1329 & Valid \\
\hline Image & CM4 & 0.872 & 0.1329 & Valid \\
\hline \multirow[t]{2}{*}{$\left(\mathbf{X}_{2}\right)$} & CM5 & 0.895 & 0.1329 & Valid \\
\hline & CM6 & 0.906 & 0.1329 & Valid \\
\hline \multirow[t]{3}{*}{ Variables } & Item & r-value & r-table $5 \%(\mathrm{~N}=216)$ & Decision \\
\hline & CM7 & 0.894 & 0.1329 & Valid \\
\hline & CM8 & 0.738 & 0.1329 & Valid \\
\hline
\end{tabular}




\begin{tabular}{|c|c|c|c|c|}
\hline Variables & Item & r-value & r-table $5 \%(\mathrm{~N}=216)$ & Decision \\
\hline & PK1 & 0.876 & 0.1329 & Valid \\
\hline & PK2 & 0.895 & 0.1329 & Valid \\
\hline & PK3 & 0.887 & 0.1329 & Valid \\
\hline Perceived & PK4 & 0.869 & 0.1329 & Valid \\
\hline Quality & PK5 & 0.838 & 0.1329 & Valid \\
\hline \multirow[t]{6}{*}{$(\mathbf{Y})$} & PK6 & 0.835 & 0.1329 & Valid \\
\hline & PK7 & 0.852 & 0.1329 & Valid \\
\hline & PK8 & 0.788 & 0.1329 & Valid \\
\hline & PK9 & 0.872 & 0.1329 & Valid \\
\hline & MB1 & 0.890 & 0.1329 & Valid \\
\hline & MB2 & 0.903 & 0.1329 & Valid \\
\hline Purchase & MB3 & 0.910 & 0.1329 & Valid \\
\hline Intention & MB4 & 0.864 & 0.1329 & Valid \\
\hline \multirow[t]{3}{*}{$(\mathrm{Z})$} & MB5 & 0.880 & 0.1329 & Valid \\
\hline & MB6 & 0.887 & 0.1329 & Valid \\
\hline & MB7 & 0.890 & 0.1329 & Valid \\
\hline
\end{tabular}

Source: Processed by researchers

The Table of Validity Test Results shows that the overall results per item have a calculated r-value greater than the $r$ table value, namely 0.1329 . It can be concluded that the indicators used in this study are valid. 


\section{Reliability Test}

A reliability test is a test tool that aims to see whether the research instrument is reliable and trustworthy. If the research variables use reliable and trustworthy instruments, the research results can also have a high level of confidence (Juliandi et al., 2014). To test reliability, cronbach's alpha method is used, where the indicator is considered reliable if it has a reliability coefficient value (Cronbach's alpha) greater than 0.6.

Table 3. Reliability Test Results

\begin{tabular}{ccc}
\hline Variables & Cronbach's Alpha & Explanation \\
\hline $\begin{array}{c}\text { Country of Origin } \\
\text { (X1) }\end{array}$ & 0,952 & Reliable \\
Brand Image & 0,947 & Reliable \\
$(\mathrm{X} 2)$ & Reliable \\
Perceived Quality & 0,954 & Reliable \\
(Y) & & \\
Purchase Intention & 0,955 &
\end{tabular}

Source: Processed by researchers

In the Table of Reliability Test Results, it shows that the Cronbach's alpha value in each variable is greater than 0.6 , namely the Country of Origin variable (X1) with a Cronbach's alpha value of 0.952 , brand image (X2) of 0.947 , perceived quality (Y) of 0.954 , and buying interest $(Z)$ of 0.955 . It can be concluded that all indicators used in this study are reliable as a means of measuring data.

\section{Confirmatory Factor Analysis (CFA)}

Confirmatory factor analysis (CFA) is a technique used in SEM to determine whether the indicator variable forms the latent variable under study (Haryono, 2016). Confirmatory Factor Analysis (CFA) to test the path analysis of Structural Equation Modeling (SEM) by operating the LISREL version 8.80 application for testing research models (Setyawan et al., 2020). 


\section{Full Model SEM}

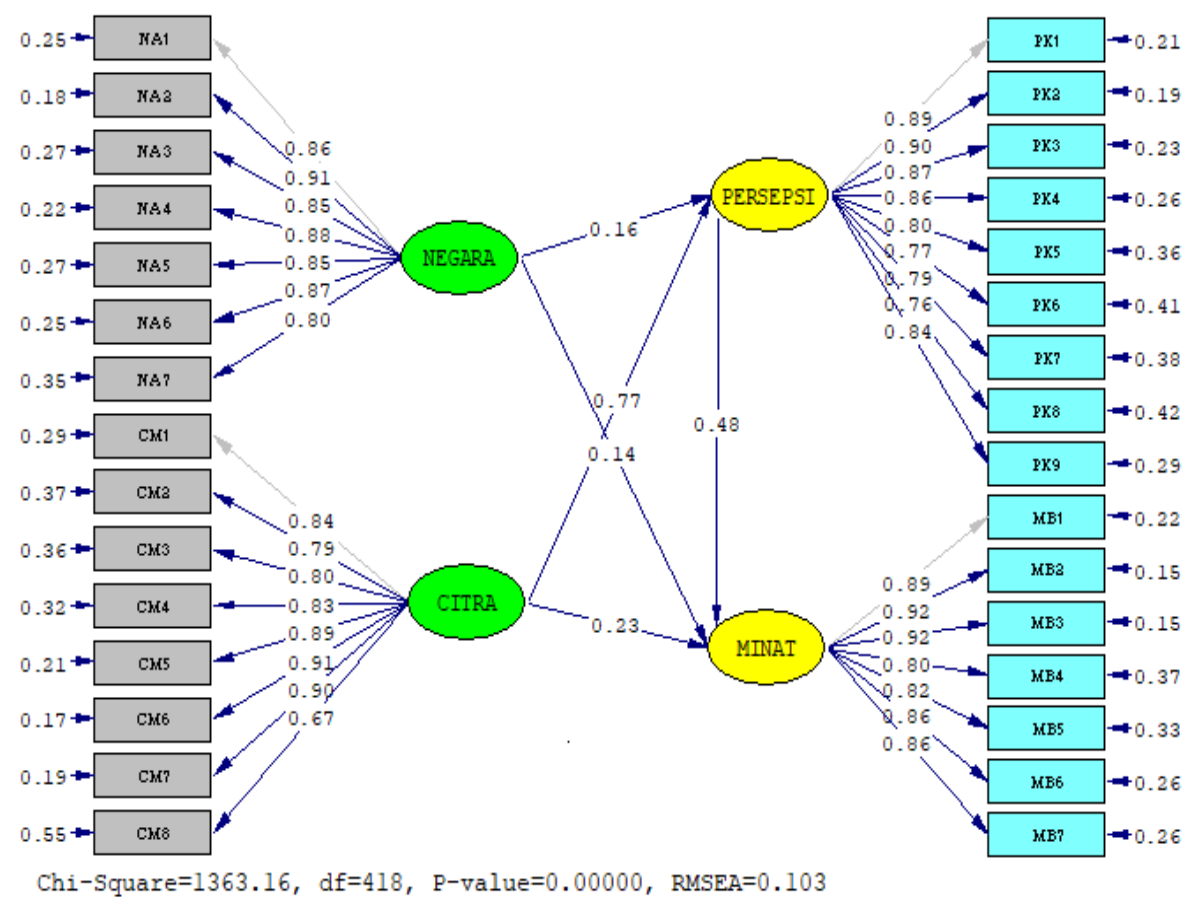

Figure 2. Full Model SEM

Source: Processed by researchers

Table 4. Full Model SEM

\begin{tabular}{lccc}
\hline Goodness of Fit Indices & Cut off Value & Results & Conclusions \\
\hline Chi Square & Expected Small & 1363.16 & bad fit \\
& $(\mathrm{p} \geq 0,05)$ & $(\mathrm{p}=0,0)$ & \\
GFI & $\geq 0,90$ & 0,71 & $\mathrm{bad} f i t$ \\
RMSR & $<0,05$ & 0,09 & $\mathrm{bad} \mathrm{fit}$ \\
RMSEA & $0,05 \leq$ RMSEA $\leq 0,08$ & 0,10 & bad fit \\
AGFI & $\geq 0,90$ & 0,66 & bad fit \\
TLI/NNFI & $\geq 0,90$ & 0,97 & good fit \\
CFI & $\geq 0,90$ & 0,98 & good fit \\
\hline
\end{tabular}

Source: Processed by researchers

Based on the results in Table 4 Full Model SEM, shows that the model does not meet the requirements, because it does not meet the goodness of fit criteria. If the model does not meet the expected criteria, it is necessary to make modifications suggested by the LISREL 
program, namely using modification indices. Modifications can be made by adding paths or adding error covariances. The researcher chose to make modifications by adding error covariances.

\section{Fit Model SEM}

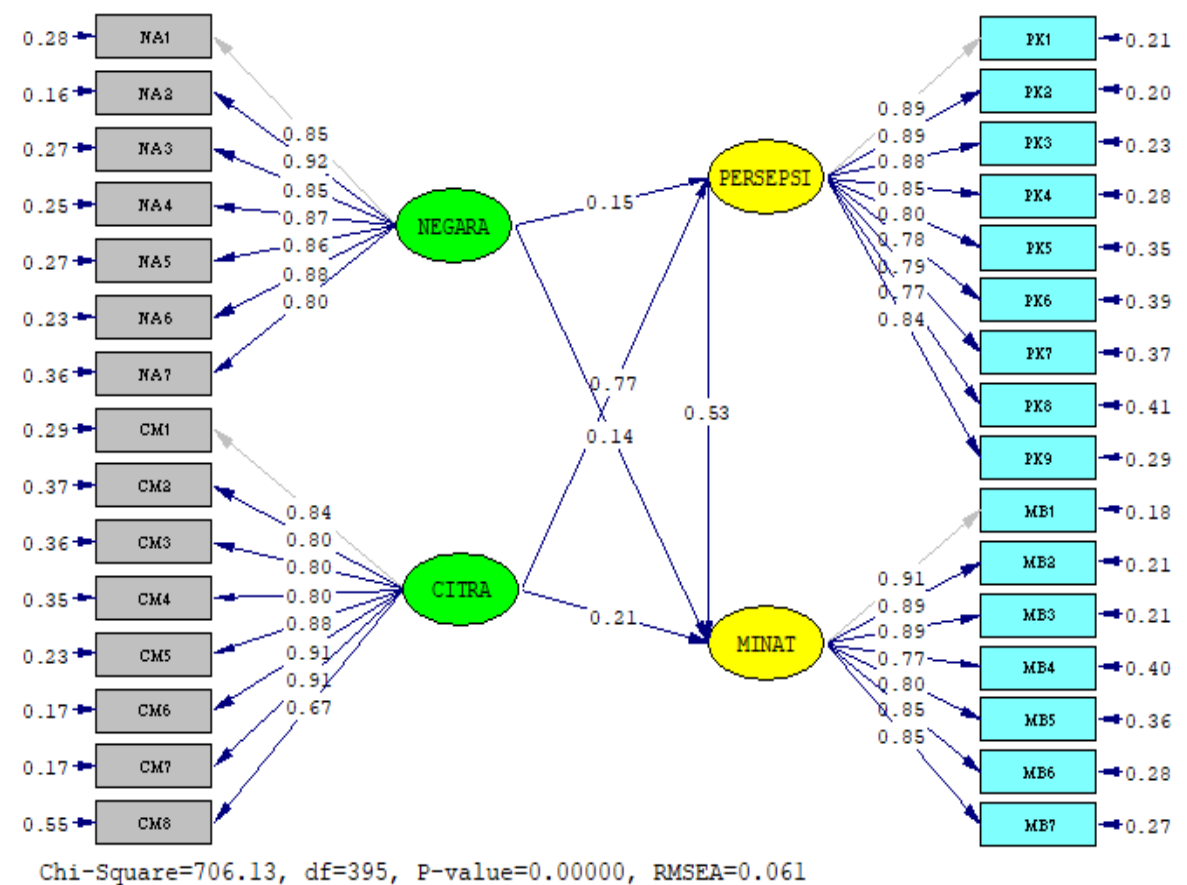

Figure 3. Fit Model SEM

Source: Processed by researchers

Table 5. Fit Model SEM

\begin{tabular}{lccc}
\hline Goodness of Fit Indices & Cut off Value & Results & Conclusion \\
\hline Chi Square & Expected Small & 706,13 & bad fit \\
& $(\mathrm{p} \geq 0,05)$ & $(\mathrm{p}=0,0)$ & \\
GFI & $\geq 0,90$ & 0,83 & marginal fit \\
RMSR & $<0,05$ & 0,07 & bad fit \\
RMSEA & $0,05 \leq$ RMSEA $\leq 0,08$ & 0,06 & good fit \\
AGFI & $\geq 0,90$ & 0,78 & bad fit \\
Goodness of Fit Indices & Cut off Value & Results & Conclusion \\
TLI/NNFI & $\geq 0,90$ & 0,99 & good fit \\
CFI & $\geq 0,90$ & 0,99 & good fit \\
\hline
\end{tabular}




\section{Source: Processed by researchers}

Based on the results in Table 5 Fit Model SEM, the modification suggested by the LISREL program has been carried out using modification indices. After modification, out of 31 indicators, there were no wasted indicators, because all indicators had a loading factor value above 0.5 . And, after adding error covariances, it shows an increase in the goodness of fit results. Where the model can be said to be quite good.

\section{Direct and Indirect Effect Test}

The direct and indirect effect test can be done by using SEM analysis using LISREL software version 8.80. The results of the direct effect can later be seen in the BETA and GAMA charts on the LISREL output, while the results of the indirect effect and the total effect formed on each variable can be seen in the chart of the indirect effect of KSI (exogenous latent variables) on ETA (endogenous latent variables) on LISREL output.

Table 6. Direct and Indirect Effect Test

\begin{tabular}{llcccc}
\hline \multicolumn{1}{c}{$\begin{array}{c}\text { Independent } \\
\text { Variables }\end{array}$} & & $\begin{array}{c}\text { Dependent } \\
\text { Variables }\end{array}$ & $\begin{array}{c}\text { Direct } \\
\text { Effect }\end{array}$ & $\begin{array}{c}\text { Indirect } \\
\text { Effect }\end{array}$ & $\begin{array}{c}\text { Total } \\
\text { Effect }\end{array}$ \\
\hline Country of Origin & $\rightarrow$ & Perceived Quality & 0,15 & & \\
Brand Image & $\rightarrow$ & Perceived Quality & 0,77 & & \\
Country of Origin & $\rightarrow$ & Purchase & 0,14 & 0,08 & 0,22 \\
Brand Image & $\rightarrow$ & Intention & & & \\
& & Purchase & 0,21 & 0,41 & 0,62 \\
Perceived Quality & $\rightarrow$ & Intention & & & \\
& & Purchase & 0,53 & & \\
\hline
\end{tabular}

Source: Processed by researchers

In Table 6. Direct and Indirect Effect Test, the variable of the country of origin (X1) has a direct effect on perceived quality (Y) of 0.15. Brand image (X2) has a direct effect on perceived quality (Y) of 0.77 , and perceived quality $(\mathrm{Y})$ has a direct effect on purchase intention $(Z)$ with a value of 0.53 .

The variable of the country of origin (X1) on purchase intention $(\mathrm{Z})$ has a direct effect with a value of 0.14 and indirectly affects a value of 0.08 so that the total value of the effect of the country of origin on purchase intention is 0.22 . While the brand image 
variable (X2) on purchase intention (Z) has a direct effect with a value of 0.21 and an indirect effect with a value of 0.41 , so the total effect value of brand image on purchase intention is 0.62 . The value of the indirecteffect is caused by the role of perceived quality as an intervening variable between the relationship between country of origin and brand image on purchase intention.

\section{Hypothesis Test Results}

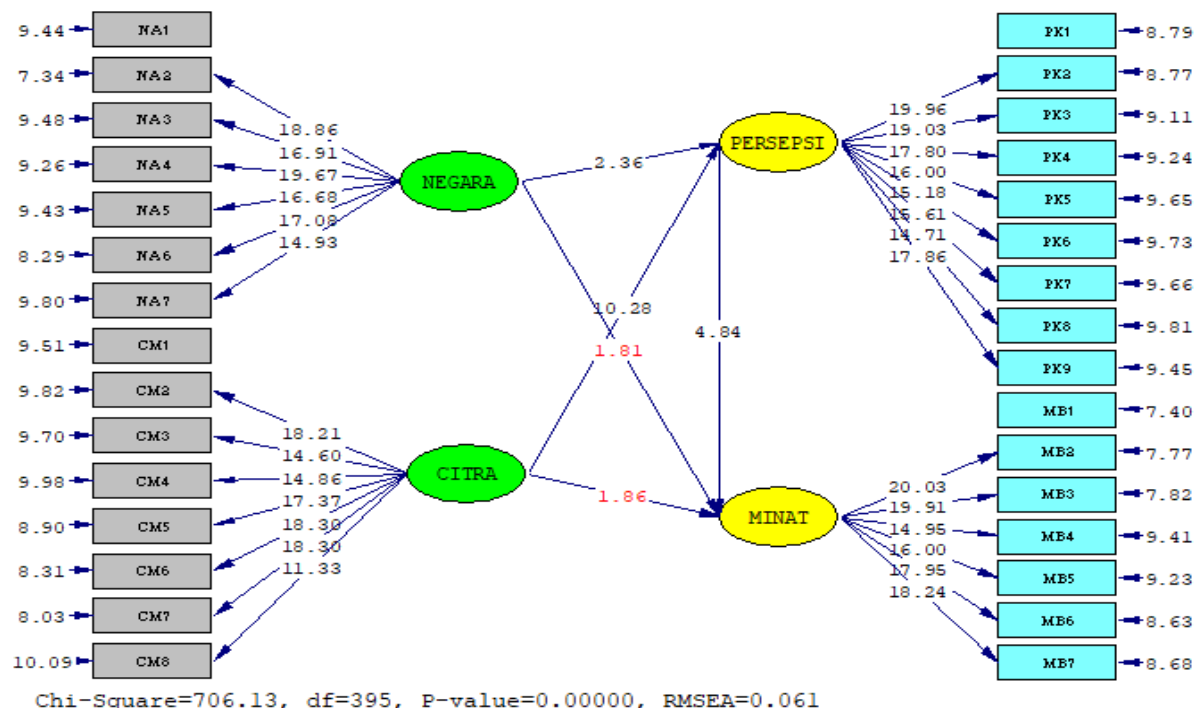

Figure 4. Fit Model SEM

Source: Processed by researchers

Table 7. Hypothesis Test Results

\begin{tabular}{|c|c|c|c|c|c|c|}
\hline Hypothesis & $\begin{array}{c}\text { Independent } \\
\text { Variables }\end{array}$ & & $\begin{array}{c}\text { Dependent } \\
\text { Variables }\end{array}$ & $\begin{array}{c}\text { Standardized } \\
\text { Total Effect }\end{array}$ & T-Value & Interpretation \\
\hline H1 & $\begin{array}{c}\text { Country of } \\
\text { Origin }\end{array}$ & $\rightarrow$ & $\begin{array}{c}\text { Perceived } \\
\text { Quality }\end{array}$ & 0,15 & 2,36 & $\begin{array}{l}\text { Positive } \\
\text { Significant }\end{array}$ \\
\hline $\mathrm{H} 2$ & Brand Image & $\rightarrow$ & $\begin{array}{c}\text { Perceived } \\
\text { Quality }\end{array}$ & 0,77 & 10,28 & $\begin{array}{l}\text { Positive } \\
\text { Significant }\end{array}$ \\
\hline H3 & $\begin{array}{l}\text { Country of } \\
\text { Origin }\end{array}$ & $\rightarrow$ & $\begin{array}{l}\text { Purchase } \\
\text { Intention }\end{array}$ & 0,22 & 1,81 & $\begin{array}{l}\text { Positive Not } \\
\text { Significant }\end{array}$ \\
\hline $\mathrm{H} 4$ & Brand Image & $\rightarrow$ & $\begin{array}{l}\text { Purchase } \\
\text { Intention }\end{array}$ & 0,62 & 1,86 & $\begin{array}{l}\text { Positive Not } \\
\text { Significant }\end{array}$ \\
\hline
\end{tabular}




\begin{tabular}{|c|c|c|c|c|c|c|}
\hline Hypothesis & $\begin{array}{c}\text { Independent } \\
\text { Variables }\end{array}$ & & $\begin{array}{c}\text { Dependent } \\
\text { Variables }\end{array}$ & $\begin{array}{c}\text { Standardized } \\
\text { Total Effect }\end{array}$ & T-Value & Interpretation \\
\hline H5 & $\begin{array}{c}\text { Perceived } \\
\text { Quality }\end{array}$ & $\rightarrow$ & $\begin{array}{l}\text { Purchase } \\
\text { Intention }\end{array}$ & 0,53 & 4,84 & $\begin{array}{l}\text { Positive } \\
\text { Significant }\end{array}$ \\
\hline H6 & $\begin{array}{c}\text { Country of } \\
\text { Origin }\end{array}$ & $\begin{array}{c}\text { Perceived } \\
\text { Quality }\end{array}$ & $\begin{array}{l}\text { Purchase } \\
\text { Intention }\end{array}$ & 0,08 & 2,12 & $\begin{array}{l}\text { Positive } \\
\text { Significant }\end{array}$ \\
\hline H7 & Brand Image & $\begin{array}{c}\text { Perceived } \\
\text { Quality }\end{array}$ & $\begin{array}{l}\text { Purchase } \\
\text { Intention }\end{array}$ & 0,41 & 4,50 & $\begin{array}{l}\text { Positive } \\
\text { Significant }\end{array}$ \\
\hline
\end{tabular}

\section{Source: Processed by researchers}

If the t-value of the structural equation model is greater than 1.96 , it can be said that there is a significant influence between variables, and if the t-value is less than 1.96 it indicates that there is no significant influence between variables. Then if the resulting value is positive, it shows that the effect is unidirectional.

\section{Results}

H1: Country of origin on perceived quality has a standardized total effects value are 0.15 , and the t-value is more significant than 1.96 , which is equal to 2.36 . So, that the first hypothesis that country of origin affects the perceived quality was accepted. The relationship between the two variables is positively signif icant. These results follow the research conducted by Abdelkader (2015) and Le et al. (2017), which states that the country of origin has a significant effect on perceived quality.

$\mathrm{H} 2$ : Brand image variables on perceived quality have a standardized value total effects value of 0.77 , and the $t$-value is more significant than 1.96 , equal to 10.28 . So, that the second hypothesis is that brand image affects the perceived quality was accepted. The relationship between the two variables is positively significant. These results follow the research conducted by Wang \& Tsai (2014) dan Khan et al. (2015) which states that the brand image has a significant effect on perceived quality.

H3: Country of origin on purchase intention has a standardized total effects value of 0.22 , and the t-value is smaller than 1.96 , which is 1.81 . So that the third hypothesis, country of origin affects purchase intention, was not accepted. The relationship between the two variables is positive, not significant. This is appropriate with research conducted by Setiadi et al. (2018) dan Le et al. (2017), showing that the country of origin does not influence purchase intention. 
$\mathrm{H} 4$ : Brand image on purchase intention has a standardized total effects value of 0.62 , and the $\mathrm{t}$-value is smaller than 1.96 , which is 1.86 . So, that the fourth hypothesis of a brand image affects purchase intention was not accepted. The relationship between the two variables is positive, not insignificant. These results are consistent with research conducted by Ali et al. (2017) and Foster \& Johansyah (2019), which shows that brand image does not significantly affect purchase intention.

$\mathrm{H} 5$ : Perceived quality on purchase intention has a standardized total effects value of 0.53 , and the $t$-value is more significant than 1.96 , which is equal to 4.84 . So, that the fifth hypothesis is perceived quality affects purchase intention is accepted. The relationship between the two variables was positively significant. These results follow the research conducted by Yunus \& Rashid (2016), which shows there is a significant influence between product perceived quality and purchase intention.

H6: Country of origin on purchase intention, through perceived quality has value standardized total effects of 0.08 , and the $t$-value is more-greater than 1.96 , which is equal to 2.12. So, the hypothesis that the six-country of origin influence purchase intention through perceived quality was accepted. The relationship between the two variables is positively significant. The country of origin indirectly influences purchase intention with a value amounting to 0.08 , which is the effect of perceived quality as an intervening variable. These results follow the research conducted by Rafida \& Saino (2015), which shows a positive influence between countries of origin on purchase intention and perceived quality as an intervening variable.

H7: Brand image on purchase intention, through perceived quality has value standardized total effects of 0.41 , and the $t$-value is more-greater than 1.96 , which is 4.50 . So, that is a hypothesis that the seventh brand image affects purchase intention through perceived quality was accepted. The relationship between the two variables is positively significant. The brand image indirectly influences purchase interest with a value amounting to 0.41 , which is the effect of perceived quality as an intervening variable. According to research conducted by Ali et al. (2020), the result shows that the product perceived quality can be a mediator variable on the relationship between brands image and consumer intention to purchase. 


\section{Discussions}

Country of origin has a positive and significant effect on perceived quality. This shows that the better the reputation of the country of origin of a brand, the consumer's perception of the product quality of a brand is also getting better if the country of origin of the Oppo smartphone is a country with a good reputation, the better the consumer's perception of the quality of the Oppo smartphone in the minds of consumers.

Brand image has a positive and significant effect on perceived quality. This shows that the better the image or reputation of a brand, the consumer's perception of the product quality of a brand is also getting better. Therefore, the positive image built by Oppo itself will lead to a positive perception of quality in the minds of consumers about Oppo smartphone products.

The country of origin has a positive but not significant effect on purchase intention. This shows that the excellent reputation of a brand or product's country of origin cannot generate consumer interest in making a purchase. Therefore, Oppo only needs to focus on improving the quality of its products and conducting appropriate promotions so that consumer buying interest can emerge.

Brand image has a positive but not significant effect on purchase intention. This shows that a brand's good image or reputation cannot generate consumer interest in making a purchase. Therefore, Oppo only needs to focus on improving the quality of its products and conducting appropriate promotions so that consumer buying interest can emerge. Perception of quality has a positive and significant effect on purchase intention. This shows that the better the consumer's perception of the quality of a product, the higher the consumer's interest in purchasing a product. Therefore, the excellent quality of the Oppo smartphone will generate consumer buying interest.

Country of origin has a positive and significant effect on purchase intention through perceived quality. It shows that. A good reputation from the country of origin of the product will foster a good quality perception in the minds of consumers, which can stimulate consumer buying interest. Therefore, a good reputation from Oppo's country of origin will lead to the perception that Oppo originating from that country is a brand that can create high-quality products, where high-quality products are more attractive to consumers. 
Brand image has a positive and significant effect on purchase intention through perceived quality. This shows that a good image or reputation of a brand will foster a good quality perception in the minds of consumers, which can stimulate consumer buying interest. Therefore, Oppo's good reputation and the image will give rise to the perception that Oppo is a brand that can create high-quality products, where high-quality products are more attractive to consumers.

\section{CONCLUSION}

The first hypothesis is that the country-of-origin variable (X1) has a positive and significant effect on perceived quality (Y) is accepted. The second hypothesis is that the brand image variable (X2) has a positive and significant effect on perceived quality (Y) is accepted. The third hypothesis, namely the country-of-origin variable (X1), has a positive and significant effect on purchase intention $(Z)$ is not accepted. The fourth hypothesis is that the brand image variable (X2) has a positive and significant effect on purchase intention $(Z)$ is not accepted. The fif th hypothesis, namely, the perceived quality variable (Y) has a positive and significant effect on purchase intention $(\mathrm{Z})$, is accepted. The sixth hypothesis is that the country-of-origin variable (X1) affects purchase intention (Z) through perceived quality (Y) is accepted. The seventh hypothesis is that the brand image variable (X2) affects purchase intention $(\mathrm{Z})$ through perceived quality $(\mathrm{Y})$ is accepted.

Implications for management: Oppo must maintain or improve its ability to produce highquality smartphone products. In addition, Oppo needs to show innovations such as using solid materials to make smartphones but can be recycled to reduce electronic waste pollution. This will improve Oppo's country of origin, namely China, as a country that is skilled in production. Oppo must improve its brand image, namely as a smartphone brand that always releases smartphones with sophisticated and latest features to meet consumer expectations. In addition, Oppo must also increase its promotions, such as through advertisements on television or social media, to build an image as a product that has prestige. Oppo must continue to improve the quality of its products, both in terms of performance and physical endurance of its smartphone products. In addition, Oppo also needs to maintain a match between what is promoted and the actual product quality when 
used. So that consumer perceptions of the quality of Oppo smartphones also improve. Consumer interest can arise because of perceptions about the quality of the product or the brand image of the product. Therefore, to maintain and increase consumer buying inte rest, Oppo must attract consumers' attention in ways such as making attractive packaging, holding promotions in the form of discounts, creating products with technology that is not owned by competing products.

Implications for academics

1. Academically, this research seeks to increase knowledge related to the country of origin, brand image, perceived quality, and purchase intention.

2. As consideration for conducting further research related to smartphone sales.

3. This research can be a reference and consideration for academics in choosing smartphones brand.

4. Can help with daily life problems at least through research can get answers that are being faced.

5. The results of this study have implications for Oppo smartphones that brand image and perceived quality are the most effective for growing buying interest.

Academic advice

1. Adding research reference sources such as marketing management books so that research can use better theories. Also, adding the latest published journals so that researchers can use the latest research results that are relevant to current conditions.

2. Research can be developed by increasing the number of respondents to more than 200 respondents, developing target respondents to become smartphone users in Jabodetabek with more diverse occupational backgrounds. Also, selecting more specific characteristics of respondents to get respondents who are following the research.

3. Research can be developed to not only focus on one smartphone brand but also all smartphone brands in Indonesia. 
4. Using indicators/statements that are more reliable and easier for respondents to understand, so as not to cause differences in views or understanding in responding to statements in the questionnaire.

\section{REFERENCES}

Aaker, D. A., \& Biel, A. L. (2009). Brand Equity and Advertising: Advertising Role in Building Strong Brands. Lawrence Erlbaum Associates, Inc.

Abdelkader, O. A. (2015). Influences of Country of Origin on Perceived Quality \& Value According to Saudi Consumers of Vehicles. International Journal of Marketing Studies, 7(1), 93-105. https://doi.org/10.5539/ijms.v7n1p93

Ahn, S. (2015). The Effect of Luxury Product Pricing on Consumers' Perception About CSR Activities. Academy of Marketing Studies Journal (AMSJ), 19(3), 1-14.

Ali, A., Ali, A., \& Sherwani, M. (2017). Shaping Halal Into a Brand? Factors Affecting Consumers' Halal Brand Purchase Intention. Journal of International Food \& Agribusiness $\quad$ Marketing, 29(3), 234-259. https://doi.org/10.1080/08974438.2017.1312657

Ali, A., Sherwani, M., Ali, A., Ali, Z., \& Sherwani, M. (2020). Investigating The Antecedents of Halal Brand Product Purchase Intention: an Empirical Investigation. Journal of Islamic Marketing. https://doi.org/10.1108/JIMA-03-2019-0063

Arafah, W., Lukito, N., \& Rikang, R. (2019). Antecedents From Purchase Intention of Retail Brand "X": Evidence from Indonesia. Academy of Marketing Studies Journal (AMSJ), 23(4), 1-14.

Assael, H. (2002). Consumer Behavior \& Marketing Action (4 ed.). PWS-Kent Publishing Company.

Belch, G. E. (2004). Advertising \& Promotion: An Integrated Marketing Communications Perspective - 6 th edition (6 ed.). The McGraw Hill.

Budiastari, S. (2018). Pengaruh Kualitas Produk, Persepsi Harga, dan Citra Merek terhadap Kepuasan dan Loyalitas Pelanggan Beton Siap Pakai Holcim di Jakarta. Jurnal Dinamika Manajemen dan Bisnis (JDMB), 1(1), 87-106. https://doi.org/10.21009/JDMB.01.1.4 
Cateora, P. R., \& Graham, J. L. (1999). International Marketing (1 ed.). McGraw-Hill MA.

Choudhuri, S. (2018). Bearings of Perceived Product Quality, Skepticism towards Store Promotion and Price Orientation on Online Purchase Intention: A First-Hand Reconnaissance. International Journal of Supply Chain Management (IJSCM), 7(5), 939-947.

Diamantopoulos, A., \& Zeugner-Roth, K. P. (2011). "Country of Origin" as Brand Element. In D. Bello \& D. Griffith (Ed.), Wiley international encyclopedia of marketing (hal. 18-22). Wiley. https://doi.org/10.1002/9781444316568.wiem06004

Dinata, J., Kumadji, S., \& Hidayat, K. (2015). Country of Origin, dan Pengaruhnya terhadap Persepsi Kualitas dan Minat Beli (Survei pada Calon Konsumen yang Berminat Membeli iPad di Indonesia). Jurnal Administrasi Bisnis (JAB), 25(1).

Edwards, A. L. (1957). Techniques of attitude scale construction. NY: AppletonCentury-Crofts.

Erdogmus, I., \& Turan, I. B.-. (2012). The Role of Personality Congruence, Perceived Quality and Prestige on Ready to Wear Brand Loyalty. Journal of Fashion Marketing and Management, 16(4), 399-417. https://doi.org/10.1108/13612021211265818

Fauziyyah, S., Dimya, M., \& Suryaningsih, I. B. (2018). Pengaruh Negara Asal terhadap Niat Pembelian melalui Citra Merek oleh Konsumen Sepatu di Kota Bandung. Jurnal Bisnis dan Manajemen, 12(2), 170-181.

Ferdinand, A. (2002). Pengembangan Minat beli Merek Ekstensi. Badan Penerbit Universitas Diponegoro.

Fishbein, M., \& Ajzen, I. (1975). Belief, Attitude, Intention, and Behavior: An Introduction to Theory and Research. Addison-Wesley Publishing Company.

Foster, B., \& Johansyah, M. D. (2019). EWOW'S Strength on Brand Image and Brand Trust and its' Impact on Interest to Buy IPhone Smartphone Products. International Journal of Innovation, Creativity and Change (IJICC), 9(12), 79-93.

Garvin, D. A. (1987). Competing on the Eight Dimension Of Quality. Harvard Business Review. 
Gibran, M. I. Al. (2018). Pengaruh Citra Negara, Citra Merek, dan Negara Asal terhadap Minat Beli pada Smartphone di Indonesia. Jurnal Manajemen Bisnis dan Kewirausahaan, 2(6), 12-17.

Hair Jr, J. F., Black, W. C., Babin, B. J., \& Anderson, R. E. (2010). Multivariate Data Analysis (7 ed.). Pearson.

Hanna, F. O. (2019). The Effect of Country of Origin and Brand Image on Perceived Quality and Interest to Buy (Study of Polytron Product). International Journal of Economics \& Business (Zambrut), 3(2), 284-292.

Haryono, S. (2016). Metode SEM (Untuk Penelitian Manajemen dengan AMOS, LISREL, PLS) (H. Mintardja (ed.); 1 ed.). PT. Intermedia Personalia Utama.

Hawkins, D. I., \& Mothersbaugh, D. L. (2014). Consumer Behavior: Building Marketing Strategy (12 ed.). McGraw-Hill Education.

Hien, N. N., Phuong, N. N., Tran, T. Van, \& Thang, L. D. (2020). The Effect of Country of Origin Image on Purchase Intention: The Mediating Role of Brand Image and Brand Evaluation. Management Science Letters, 10(6), 1205-1212. https://doi.org/10.5267/j.msl.2019.11.038

Jaffe, E. D., \& Nebenzahl, I. D. (2006). National Images and Competitive Advantage: The Theory and Practice of Place Branding. Copenhagen Business School Press.

Juliandi, A., Irfan, \& Manurung, S. (2014). Metodologi Penelitian Bisnis (Konsep dan Aplikasi) (F. Zulkarnain (ed.); 1 ed.). UMSU PRESS.

Khan, N., Rahmani, S. H. R., Hoe, H. Y., \& Chen, T. B. (2015). Causal Relationships among Dimensions of Consumer-Based Brand Equity and Purchase Intention: Fashion Industry. International Journal of Business and Management, 10(1), 172. https://doi.org/10.5539/ijbm.v10n1p172

Knight, G. A., \& Calantone, R. J. (2000). A Flexible Model of Consumer Country-ofOrigin Perceptions: A Cross-Cultural Investigation. International Marketing Review, 17(2), 127-145. https://doi.org/10.1108/02651330010322615

Kyo, S. J., Saithibvongsa, P., \& Hyeok, C. J. (2019). Country Image, Perceived Product Quality and Purchase Intention: The Moderating Roles of Quality Warranty Certificate and Country Image Transferred Strategies. International Journal of Economics and Management, 1(3), 10-23. 
Laroche, M., Papadopoulos, N., Heslop, L. A., \& Mourali, M. (2005). The Influence of Country Image Structure on Consumer Evaluations of Foreign Products. International Marketing Review, 22(1), 96-115. https://doi.org/10.1108/02651330510581190

Le, H. T., Nguyen, P. V, Ho, P. D., \& Chi, N. D. (2017). Effect of Country of Origin and Product Features on Customer Purchase Intention: A Study of Imported Powder Milk. Academy of Marketing Studies Journal (AMSJ), 21(1), 1-19. https://doi.org/10.1504/IJBIR.2019.10021686

Lee, H.-M., Chen, T., \& Guy, B. S. (2014). How the Country-of-Origin Image and Brand Name Redeployment Strategies Affect Acquirers'Brand Equity After a Merger and Acquisition. Journal of Global Marketing, 27(3), 191-206. https://doi.org/10.1080/08911762.2014.909550

Listiana, E. (2015). Country of Origin Image and It's Impact on Brand Association, Perceived Quality and Brand Loyalty. Journal of Marketing and Consumer Research, 10, 19-35.

Martati, I., Suminto, \& Pristanti, H. (2020). The Mediating Role of Perceived Quality for Purchase Intention of Motor Scooter Matic. International Journal of Innovation, Creativity and Change (IJICC), 14(5), 496-511.

Mehta, A. M., \& Tariq, M. (2020). How Brand Image and Perceived Service Quality Affect Customer Loyalty through Customer Satisfaction. Academy of Marketing Studies Journal (AMSJ), 24(1), 1-10.

Mohamed, R. N., Mohamad, B., Borhan, H., \& Osman, I. (2019). The Determinant Factors of Supply Chain Management on Purchase Intention of an International Branded Apparels Status Quo. International Journal of Supply Chain Management (IJSCM), 8(3), 677-684.

Nugraha, H. M. (2019). Yuk, Ketahui 10 Kelebihan dan Kekurangan HP Oppo Ini! https://carisinyal.com/kelebihan-dan-kekurangan-hp-oppo/

Nurhandayani, A., Syarief, R., \& Najib, M. (2019). The Impact of Social Media Influencer and Brand Images to Purchase Intention. Journal of Applied Management (JAM), 17(4), 650-661. https://doi.org/10.21776/ub.jam. 2019.017.04.09 
Parlina, G. A. (2017). Pengaruh Country of Origin terhadap Minat Beli Smartphone Oppo dengan Perceived Quality sebagai Variabel Intervening (Studi pada Pengunjung Plaza Millennium) [Universitas Sumatera Utara]. http://repository.usu.ac.id/handle/123456789/65823

Purwanto, E. (2019, Februari 21). 2018: Pengguna Smartphone Indonesia Tembus 103 Juta Orang. ayooberita.com. https://www.ayooberita.com/berita-----2018pengguna-smartphone-indonesia-tembus-103-juta-orang

Rafida, V., \& Saino. (2015). Pengaruh Country of Origin terhadap Minat Beli dengan Perceived Quality sebagai Variabel Intervening (Studi pada Pengunjung Artomorro Selluler Kota Madiun). Jurnal Pendidikan Tata Niaga (JPTN), 3(2).

Sarwono, J. (2006). Metode Penelitian Kuantitatif dan Kualitatif (1 ed.). Graha Ilmu.

Schiffman, L., \& Kanuk, L. L. (2007). Consumer Behavior. Prentice Hall.

Setiadi, E., Adiwijaya, M., \& Subagio, H. (2018). The Impact of Brand Awareness and Country of Origin on Purchase Intention with Mediation of Self Congruity on Chinese Brand Automotive Products Wuling. Petra International Journal of Business Studies (IJBS), 1(2), 70-79. https://doi.org/10.9744/ijbs.1.2.

Setyawan, K. A., Suhud, U., \& Handaru, A. W. (2020). Satisfaction and Trust Analysis of SIPP Online BPJS Ketenagakerjaan Users: What is The Role of Ease of Use, Variations in Web Design and Functions? Jurnal Dinamika Manajemen dan Bisnis (JDMB), 3(1), 1-15.

Spears, N., \& Singh, S. N. (2004). Measuring Attitude toward The Brand and Purchase Intentions. Journal of Current Issues \& Research in Advertising, 26(2), 53-66. https://doi.org/10.1080/10641734.2004.10505164

Sugiyono. (2015). Metode Penelitian Pendidikan (Pendekatan Kuantitatif, Kualitatif, dan R\&D). CV. Alfabeta.

Sukardi. (2015). Metodologi Penelitian Pendidikan. PT. Bumi Aksara.

Syahrum, \& Salim. (2012). Metodologi Penelitian Kuantitatif (R. Ananda (ed.)). Citapustaka Media.

Talwar, A., Kaur, J., \& Duggal, V. (2020). The Impact of Myers-Briggs Personality Types (Introversion and Extroversion) on Purchase Intention towards International Fashion Brands of Millenials in India. Academy of Marketing Studies Journal 
(AMSJ), 24(1), 1-10.

Thaichon, P., \& Quach, T. N. (2015). From Marketing Communications to Brand Management: Factors Influencing Relationship Quality and Customer Retention.

Journal of Relationship Marketing, 14(3), 197-219. https://doi.org/10.1080/15332667.2015.1069523

Wang, Y.-H., \& Tsai, C.-F. (2014). The Relationship Between Brand Image and Purchase Intention: Evidence from Award Winning Mutual Funds. The International Journal of Business and Finance Research, 8(2), 27-40.

Wong, A. T.-T. (2021). A Study of Purchase Intention on Smartphones of College Students in Hong Kong. Academy of Marketing Studies Journal (AMSJ), 25(1).

Wu, L., Ju, I., \& Dodoo, N. A. (2016). Understanding the Impact of Matchup between Country-of-Origin Facets and Country Stereotypes on Advertising Effectiveness. Journal of Global Marketing, 29(4), 203-2017. https://doi.org/10.1080/08911762.2016.1185561

Yunus, N. S. N. M., \& Rashid, W. E. W. (2016). The Influence of Country of Origin on Consumer Purchase Intention: The Mobile Phones Brand from China. Procedia Economics and Finance, 37, 343-349. https://doi.org/doi.org/10.1016/S22125671(16)30135-6

Zhang, L., \& Cude, B. J. (2018). Chinese Consumers' Purchase Intentions for Luxury Clothing: A Comparison between Luxury Consumers and Non-Luxury Consumers. Journal of International Consumer Marketing (JICM), 30(5), 336-349. https://doi.org/10.1080/08961530.2018.1466225

\section{Appendix}

\section{Questionnaire Table}

\begin{tabular}{lll}
\hline Variables & Item & Source \\
\hline $\begin{array}{c}\text { The country of origin of Oppo smartphones is a } \\
\text { Country of } \\
\text { Origin }\end{array}$ & $\begin{array}{c}\text { country that is creative in production. } \\
\text { The country of origin of Oppo smartphones is a } \\
\text { country that has high technology. }\end{array}$ & $\begin{array}{c}\text { Hien et al. } \\
\text { (2020); Yasin et al. } \\
\text { (2007). }\end{array}$ \\
& The country of origin of Oppo smartphones is &
\end{tabular}
able to make products with beautiful designs. 


\begin{tabular}{|c|c|c|}
\hline Variables & Item & Source \\
\hline & $\begin{array}{l}\text { The country of origin of Oppo smartphones has } \\
\text { the ability of creative professionals. } \\
\text { The country of origin of Oppo smartphones has a } \\
\text { high quality workforce. } \\
\text { The country of origin of the Oppo smartphone is } \\
\text { a country that has prestige. } \\
\text { The country of origin of the Oppo smartphone is } \\
\text { a developed country }\end{array}$ & \\
\hline Brand Image & $\begin{array}{l}\text { Oppo smartphones are made by a trusted } \\
\text { company. } \\
\text { Oppo smartphones are made by a company that } \\
\text { is always innovating. } \\
\text { Using an Oppo smartphone gave me confidence. } \\
\text { People who use Oppo smartphones reflect } \\
\text { modern people. } \\
\text { The Oppo smartphone has an attractive } \\
\text { packaging. } \\
\text { Oppo smartphones have functions in accordance } \\
\text { with consumer desires. } \\
\text { Oppo smartphones are reliable products. } \\
\text { Oppo smartphones have a good resale value. }\end{array}$ & $\begin{array}{l}\text { Nurhandayani et } \\
\text { al. (2019). }\end{array}$ \\
\hline $\begin{array}{l}\text { Perceived } \\
\text { Quality }\end{array}$ & $\begin{array}{l}\text { Oppo smartphones are performing well. } \\
\text { Oppo smartphones have specifications in } \\
\text { accordance with consumer desires. } \\
\text { Oppo smartphones always work as they should } \\
\text { (have consistent advantages). } \\
\text { Oppo smartphones have features and capabilities } \\
\text { that match the promotion. } \\
\text { Smartphones have good staying power. } \\
\text { Oppo smartphone spare parts are easy to get. } \\
\text { The Oppo smartphone repair center is easy to get } \\
\text { to. } \\
\text { The Oppo smartphone is a luxury product. } \\
\text { The Oppo smartphone has an attractive } \\
\text { appearance. }\end{array}$ & $\begin{array}{l}\text { Abdelkader } \\
\text { (2015). }\end{array}$ \\
\hline $\begin{array}{l}\text { Purchase } \\
\text { Intention }\end{array}$ & $\begin{array}{l}\text { I am interested in buying an Oppo smartphone. } \\
\text { I would recommend an Oppo smartphone to } \\
\text { people who want to change their cellphone. } \\
\text { I would suggest buying an Oppo smartphone. } \\
\text { I prefer Oppo smartphone products than other } \\
\text { brands. } \\
\text { I prefer Oppo smartphones over other brands. } \\
\text { I am looking for more information on Oppo } \\
\text { smartphones. } \\
\text { I am looking for a promotion from an Oppo } \\
\text { smartphone. }\end{array}$ & $\begin{array}{l}\text { Nurhandayani et } \\
\text { al. (2019). }\end{array}$ \\
\hline
\end{tabular}

